\title{
Selection of Priority Cause and Effect Chains on the Strategy Map of Goals Using AHP Multiple Criteria Analysis
}

\author{
1Sanja Penić*, 2ŽeljkoDobrović \\ ${ }^{1}$ Digera Ltd, Kozjak 1 Zagreb Croatia \\ 2University of Zagreb Pavlinska 2 Varaždin, Croatia \\ *sanja.penic@digera.hr
}

\begin{abstract}
Today, when the labor market is extremely dynamic, and there is great competition, a certain level of knowledge is expected of every individual. This has influenced an increase in the number of higher education institutions, primarily in the private sector. To cope better with the growing global competition, the management of private higher education institutions is becoming increasingly aware of the needs to select the appropriate management methods. That would ensure the achievement of strategic goals and make a unique and clear methodology, easily applicable in today's turbulent environment. The paper proposes a unique management methodology which would represent a strategic management framework applicable to most private higher education institutions. The creation of a strategy map of goals by linking SWOT and BSC methods with multiple criteria decision method is described. An emphasis is placed on the application of the multiple criteria decision-making method in the objective selection of priority cause and effect chains in the BSC strategy map. The result of the application of the proposed methodological framework targets the priority cause and effect chains, i.e. strategies which would enable the achievement of vision and mission.
\end{abstract}

Keywords: Method, SWOT, BSC, AHP, management

\section{Introduction}

All areas of human knowledge are expanding rapidly, and only high-quality education can help future generations cope with such a large quantity of knowledge. Organizations do not gain significant competitive advantage only by adopting new technologies like physical assets or good management of financial assets, but through management of intangible assets such as knowledge, as well. This increases the need for knowledge and educated employees, and organizations which provide education services operate in an increasingly competitive global environment (Chen, Yang \& Shiau, 2006), and the need for successful management is imposed upon them. In Croatia we are witnessing atransition from socialism towards a vision of Western European democracy. This Local societal changes, as well as the global transformations increased the need for employees with higher education, and any additional knowledge in a particular business, becoming a competitive advantage (Doolan, 2001).Transformation (and needs for skilled employees) also affected higher education. By Act on higher education institutions (1996. Year) enabled the emergence of private HE sector in Croatia (Doolan, 2001). These schools with their activities contribute to the development of higher vocational education and train a large number of citizens for the new demands of the economy. But on this private higher schools apply rules as well as any other profit organization, they are financed from own revenues, not from the state budget. Based on these facts there is a need for effective management and continuous development, which means defining measurable objectives to facilitate the monitoring and supervision of the private high schools and the implementation of their vision and mission.

Successful management of an organization means clear definition of vision, mission and goals, and the application of appropriate methods for monitoring and management. Results should be satisfactory financial results which may improve educational and business processes, which leads to meet the expectations of students and contributes to the achievement of operational goals. However, the fact needs to be accepted that each school operates in different conditions, short-term and long-term goals and strategies of each school differ. Each school bases them on its own mission and vision, taking into account its own resources and the importance of goals as a part of the strategy. Defining measurable goals should facilitate the monitoring and control of business operations in higher education institutions, as well as the implementation of their vision and mission. All of the above is also the reason for the perceived need to create a model - a combination of multiple proven management methods, which could define generic goals for managing private higher education institutions and their control. Such a management model is 
based on the method of balanced scorecards (BSC) and AHP (Analytic Hierarchy Process) method. Those two methods can be combined with the SWOT (Strengths, Weaknesses, Opportunities, and Threats) method into a consistent management methodology. This paper shows how a combination of these methods allows us to propose an efficient methodological framework to identify goals and their mutual effects in a systematic and structured way, and to isolate the most important goals in relation to the vision and mission of the organization. Further in this paper literature review concerning BSC and AHP was described. Also the methods and the proposed framework were described

\section{Literature Review}

Several papers in the reviewed literature describe the application of combined BSC and AHP methods in different business areas. Common is the fact that the AHP method is used in the selection of priority indicators or perspective, but does not consider it necessary to observe the cause and effect links of indicators/objectives. In their work, Shojaie, Torabi and Sedighi (2012) propose an effective method for assessment of KM contributions in one of the Iranian companies with regard to four BSC perspectives i.e. financial, customer, internal business processes, and learning and growth perspectives, while Fuzzy AHP is used to determine priority indicators. Farrokhi, Aftab and Hemati (2012) apply the same method for evaluating indicators in manufacturing companies in their paper. Theriou, Demitriades and Chatzoglou (2004) provide an overview of the method used to directly link various BSC performance indicators with the goals and purpose of any enterprise, and explain how multiple criteria AHP method facilitates the linking. The authors state that this defines a framework which facilitates the strategic planning process. Erbasu and Parlakkaya (2012) recommend AHP to obtain objective decision-making results instead of making the usual subjective management assessments. The seven-stage process of application of AHP method in BSC is described. Varma, Wadhwa and Deshmukh (2008) apply the combination of the analytic hierarchy process (AHP) and the Balanced Scorecard (BSC) to evaluate the petroleum supply chain performance. The selection of factors which determine the performance of the supply chain in four BSC perspectives are based on the opinion of experts in the field. With the aim of determining the relative importance of the criteria, AHP method was applied.

E-SWOT: The origin of SWOT analysis is in the SOFT analysis -Satisfactory (present), Opportunity (future), Fault (present), Threat (future) - which is derived from research on corporate planning conducted at the Stanford Research Institute (between 1960 and 1970). After the presentation of the SOFT analysis in Zurich in 1964, it changes the name to SWOT analysis and takes the form of a matrix (Koo \& Koo, 2007). According to Dobrović (2000),"SWOT analysis was developed to help assesses an organization's maturity when accepting business changes due to changes in the environment. Although nowadays it is necessary to perform SWOT analysis, it is not powerful enough in itself to make qualitative decisions". The application of SWOT analysis does not make links between external and internal factors visible, so extended SWOT method should be used in cases where it is necessary to develop strategies and associated goals. The e-SWOT method has four stages (Tomičić \& Dobrović, 2006):

- Determining initial SWOT analysis elements (strengths, weaknesses, opportunities, threats);

- Determining the strength of influence on the achievement of goals (ranking within group of elements),

- Determining how internal strengths (S) and external opportunities (0) can be used in undoing internal weaknesses (W) and external threats (T);

- At this stage, three steps take place:

a) For defined strategies, specific activities for their implementation are determined,

b) For each of the activities a measurable goal is determined,

c) Determining the influence of certain activities on goals.

Results of the described method are a prerequisite for the creation of a balanced scorecard, and thus of a strategy map.

Balanced scorecards (BSC): According to method authors Kaplan and Norton (1996), a balanced scorecard (BSC) is a strategic management system. The method is described in their book The Balanced Scorecard, which serves as a guide for current and future implementation by monitoring measures in four categories: 1) financial implementation, 2) customers, 3) internal business processes, 4) learning and growth. The balanced scorecard method allows enterprises to face and successfully cope with globalization challenges, unstable business environments, by structuring and expanding the traditional strategic planning and management, as follows (Penić, 2008): 
- by facing the entire enterprise with a clear, shared vision, related to operations and with a structured approach to defining actions needed to achieve the vision;

- by updating relevant information from the entire organization and their efficient utilization for progress and evaluation of strategic goals;

- By strategic management of "intangible", as well as "traditional" assets by introducing new management parameters, with the common financial criteria.

In 2008, out of the top 25 most popular management tools, balanced scorecards were ranked sixth with regard to use. Out of 1430 enterprises, $53 \%$ use balanced scorecards as a tool for monitoring organization performance (Rigby \& Bilodeau, 2010). In addition, study of 309 papers (of which $77.35 \%$ are empirical studies) has confirmed the hypothesis that today this method is based on a solid theoretical model applicable in various organizations (Banchieri, Planas \& Rebull, 2011). According to author of the article, balanced scorecard as a method has been developed and improved over a number of years, so that today we have solid and applicable theoretical foundations allowing the implementation in various sectors and countries. What sets the BSC method apart from other methods to measure performance and evaluation / assessment, is the presentation of the strategy in various perspectives, thus eliminating the possibility of unnecessary strategies at higher perspectives. Moreover, in order to successfully implement BSC, perspectives and strategies must be balanced with the goals (Erbasu \& Parlakkaya, 2012). It should be noted that there are no unique BSC indicators applicable to all organizations, which is why the AHP method is used to define priorities (Shojaie, Torabi, \&Sedighi, 2012).

AHP: Analytic Hierarchy Process - AHP is one of the best known methods of scientific scenario analysis and decision-making through consistent judgment of hierarchy of goals, criteria, sub-criteria and alternatives, which together create a system for supporting the decision-making process. The conceptual and mathematical basis of the AHP method was developed by Thomas Saaty. It enables interactive formation of problem hierarchy as preparation for decision-making scenarios, followed by a top-down pair wise judgment of hierarchy elements (goals, criteria and alternatives). Finally, a synthesis of judgments is performed, and weight coefficients for each hierarchy element are determined in line with a strict mathematical model. The sum of weight coefficients of elements at each level of the hierarchy is one, which allows the decision-maker to rank all elements horizontally and vertically (Jandrić \& Srđević, 2000). From the methodological point of view, the AHP is a multiple criteria technique based on the decomposition of a complex problem into a hierarchy. The goal is at the top of the hierarchy while the criteria, sub-criteria and alternatives are located at lower levels. For example, Figure 1 shows a hierarchy consisting of a goal, three criteria and four alternatives. The hierarchy does not have to be complete; for example, an element at some level does not have to be a criterion for all elements of the sub-level, so that the hierarchy can be divided into sub-hierarchies with the only common element being the one at the top of the hierarchy (Begičević, 2009). It is a methodology that allows the evaluation of alternatives in the light of the conflict of principles and deals with issues which are emotional for stakeholders in the decision-making process (Saaty \& Begičević, 2010). An important quality in the application of this method is to check the consistency of decision-maker's judgment. During the judgment of hierarchy elements, all the way to the end of the procedure and the synthesis of results the consistency of decision-maker's reasoning is examined and the correctness obtained by ranking alternatives and criteria, as well as their weight values, is determined (Begičević, 2009).

\section{Figure 1: Example of hierarchy in AHP}

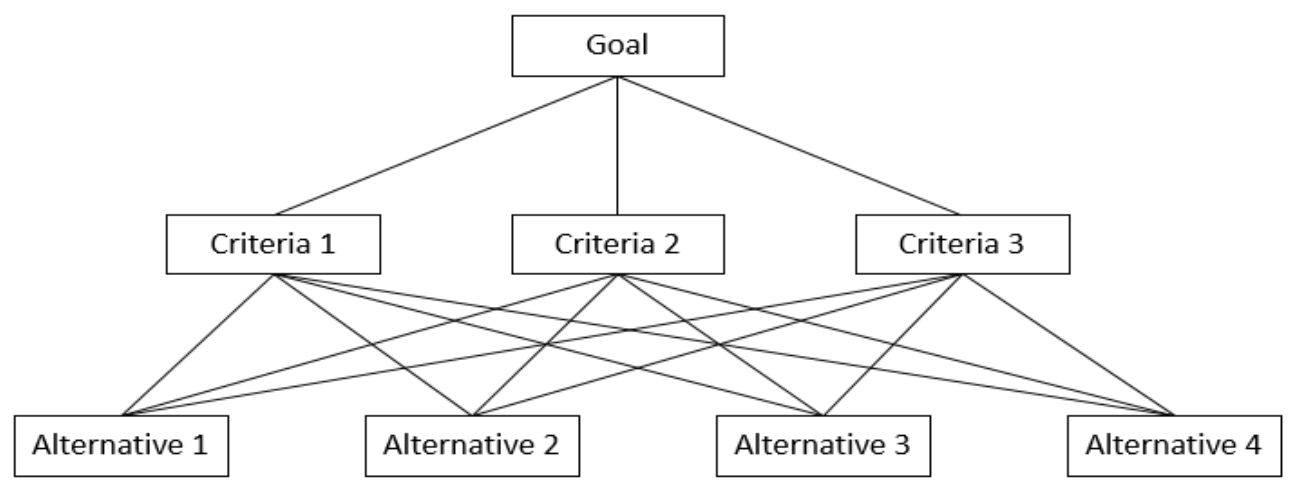

Source: Begičević N. (2009). Odlučivanje u projektnommenadžmentu. U: B. Divjak, B. (ur.) Projekti u znanosti $i$ razvoju, Europskiprogrami. TIVA TiskaraVaraždin, Fakultetorganizacije i informatike, Varaždin, 180-191. 
AHP has been applied in various fields of strategic management in which decisions have a far-reaching significance, and in which decision-makers choose a high-quality, trusted advisor in the stage of considering alternatives and determining their effects with regard to the set goals. The application of this method can be explained in four steps (Hunjak \& Jakovčević, 2003):

- Development of a hierarchy model of the decision-making problem with the goal at the top, criteria and sub-criteria at lower levels, and alternatives at the bottom of the model.

- At each level of the hierarchy structure, elements and structures are compared pair wise, where the preferences of the decision-maker are expressed using an appropriate scale with 5 levels and 4 intermediate levels of verbally described intensities and the corresponding numerical values ranging from 1-9.

- From the assessment of the relative importance of an element at the appropriate level of the problem hierarchy structure, local priorities (weights) of criteria, sub-criteria and alternatives are calculated using an appropriate mathematical model, and are then synthesized into overall alternative priorities.

- Sensitivity analysis is conducted.

AHP enables the decision-makers to structure complex problems and allows them to incorporate both objective and subjective considerations in the decision-making process (Theriou et al., 2004).

\section{Proposed Framework}

Isolating the most important strategic goals and creation of strategy map of BSC goals: Common goals, representing the starting point for the E-SWOT analysis were isolated from interviews (surveys) with deans of five private higher education institutions. All deans agreed to do the survey, so the return with regard to the sample size was 100\%. The data refer to the school year 2005/2006 (Penić, 2008).

The most important goals were isolated: Student satisfaction, Employee satisfaction, Raising the level of competitiveness, Improving the quality of teaching (Monitoring business processes), Continuous modernization of work organization of the higher education institution, Continuous modernization of equipment of the higher education institution.

Two goals are in the customer perspective - Student satisfaction and Raising the level of competitiveness, and these are considered to be strategic goals. For the competitiveness we will use the definition given by Harmon (2003) - competitive advantage occurs when an organization can create more profits from the sale of their products or services than its competitors. For each of the two strategic goals E-SWOT matrix has been created. Derived sub-goals which form the input data for the BSC strategy map are identified in the four phases described in E-SWOT chapter (Penić \&Dobrović, 2008) (example Table 1). As each goal relates to one of the perspectives of balanced scorecards, they will be marked as such, for example, financial (F) or related to customers (C).

Table 1: Strategies - Activities- Derived strategic goals - Goal Be competitive

\begin{tabular}{|c|c|c|c|c|c|}
\hline \multicolumn{6}{|c|}{ Strategies - Activities- Derived strategic goals - Goal Be Competitive } \\
\hline Strategy & $\begin{array}{l}\text { Strategy } \\
\text { description }\end{array}$ & Activities & Goal symbols & Goal description & $\begin{array}{l}\text { Effect } \\
\text { goal }\end{array}$ \\
\hline \multirow[b]{2}{*}{$\mathrm{S} 3 \rightarrow \mathrm{W} 4$} & \multirow{2}{*}{$\begin{array}{l}\text { Provide managerial } \\
\text { governance } \\
\text { schools of higher } \\
\text { education }\end{array}$} & \multirow{2}{*}{$\begin{array}{l}\text { of } \\
\text { the } \\
\text { for }\end{array}$} & C1.i1 & $\begin{array}{l}\text { Optimizing } \\
\text { business processes }\end{array}$ & C2.f2 \\
\hline & & & C1.i2 & $\begin{array}{l}\text { Updating } \\
\text { organization }\end{array}$ & $\mathrm{C} 2, \mathrm{C} 2 . \mathrm{f} 2$ \\
\hline $\mathrm{S} 2 \rightarrow \mathrm{W} 1$ & $\begin{array}{l}\text { Develop } \\
\text { programs }\end{array}$ & $\begin{array}{l}\text { Participation in } \\
\text { EU competitions } \\
\text { and projects }\end{array}$ & C1.f1 & Influx of finances & C1.f2 \\
\hline
\end{tabular}

With this structured approach to creating a strategy map, the random setting of goals is avoided, and in addition to the two strategic goals, 19 sub-goals are identified, which makes a total of 21 elements to be distributed in strategy map perspectives. All data for the creation of the strategy map of goals can be found in the last three columns of the table (Table 1) - goal symbol, goal description and the symbol of the derived goal directly affected by the goal. On the basis of the data, the strategy map of goals for private higher education institutions is structured. All the objectives from the strategy map of goals are distributed within four standard perspectives. Strategy map of goals (Brumec, Tomičić \& Brumec, 2006) is the basic graphic representation of links between the activities undertaken to achieve the strategic 
goals of the organization. Indicators used to measure the level of activities' achievement in Learning and growth and Internal processes perspectives are called cause indicators, change indicators or leading indicators, and these will, with a certain time delay, cause changes at the levels of activities' achievement in Customers and Finance perspectives, which will be expressed in effect indicators, status indicators or lagging indicators.

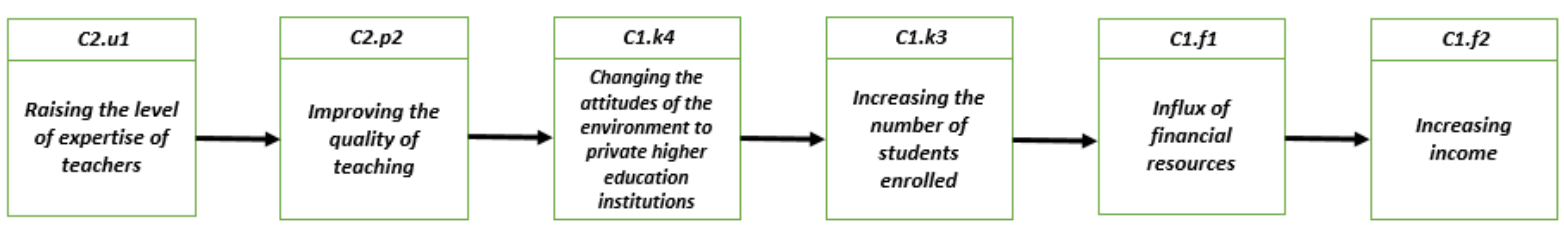

Figure 2: Example of the described chain

The logical basis for its construction is as follows: - if specific activities are undertaken which are directed at raising the level of knowledge of employees (in the Learning and Growth perspective), such as activity - Utilize (linking with EU institutions and university) and transfer knowledge and experiences, for the purpose of achieving C2.u1 "Raising the level of expertise of teachers", this will probably not have a direct influence on the goal C1.f2 "Increase income"; on the contrary, such activity will raise the cost of business operation over a period of time during which the education takes place. It is, however, expected to have a positive effect on the C2.p2 goal, which would furthermore indirectly influence the realization of the C1.k3 goal and thus of the C1.f1 goal and through it of the C2.f2 goal (Figure 2).Seeing that each activity is undertaken with a specific goal, it can be understood that the goal structure corresponds to the activity structure. This way all strategic goals and all of their derived sub-goals form a network of cause and effect links, the elements of which are distributed among individual perspectives. The level of achievement of each goal will be measured (described in more details in the following chapter) and expressed in the value of the indicator. By its structure, a strategy map is a network; some goals (e.g. C2.u2or C2.u1) have effect on multiple goals and vice versa: some dependent goals (e.g. C2.p2 or C1.f1) depend on multiple goals. With others, on the other hand, as is the case with C1.p3, both types of links are present, so they form complex nodes of strategy maps (Figure 3).

Figure 3: Strategy map of goals for private schools of higher education

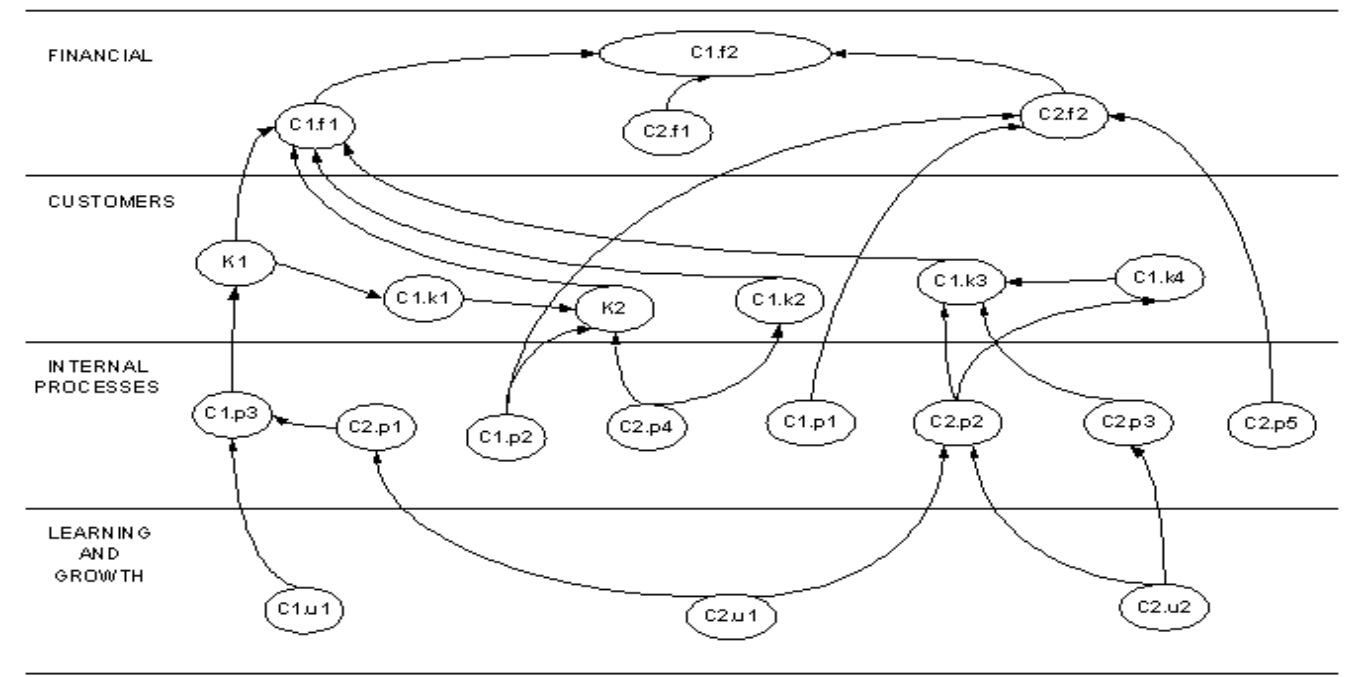

Quantifying cause and effect chains of balanced scorecards: According to Chen and Pan (2004), organizations in the service industry can apply AHP in selecting key performance indicators (KPI) within all four perspectives of balanced scorecards. In this paper, the AHP is applied to structure the balanced scorecard into a unified system of measures needed to the decision-maker. The first and most important step in the AHP process is to structure the problem as a hierarchy. Hierarchy element priorities are set using answers to questions about the dominance or importance of one element over another. One of the most commonly used software packages, the Expert Choice (EC), was used to identify priority cause and effect chains using the AHP method. The utilization of formal analytic decision-making processes enables the inclusion of numerous balanced scorecard elements in the decision-making process (Sale \& Sale, 
2005). In this way, the complexity of interactions between elements is managed, and the degree of internal evaluation is ensured to verify that the measuring of indicators is consistent. We wish to approach this analysis systematically, without neglecting the mutual effects that goals have on one another. The determination of goal weights for individual perspectives is not implemented, but rather cause and effect chains of goals are observed. Model is defined for the decision-making on the selection of the optimal alternative with regard to the set criteria for the selection of priority chains. Thus for the definition of goals in the management of private higher education institutions which need to be monitored more frequently. The main elements of the decision-making problem are goals to be achieved by the decision, alternatives of the selection and criteria applied in the selection.

Problem description: A systematic approach to building a model and creating a strategy map of cause and effect chains of goals (using the BSC method) has lead to the identification of 15 cause and effect chains. 21 goals in four perspectives of the strategy map are linked into chains which form the structure to achieve the mission and vision of private higher education institutions (Figure 3). The map has reached the optimal number of goals - 21 . However, the number of cause and effect chains (15 chains) which need to be monitored is still very complex, and it is difficult to monitor and control them all at the same time. The management of private higher education institutions has a choice:

1. monitor all cause and effect chains;

2. isolate only those chains which the management considers important for achieving the vision and mission, i.e. more frequent reporting on activities and achieved results with regard to the selected goals.

The first step defines the goal / problem, and the second selects the criteria for isolating the cause and effect chains whose elements need to be monitored more frequently for the purpose of achieving the mission and vision. To facilitate monitoring, cause and effect chains will be marked with $L x$ (example Figure 2).

The definition of the goal is as follows:

Determine the relative importance of cause and effect chains to isolate the most important chains (and appertaining measures) for the management of private higher education institutions, i.e. to implement the mission and achieve the vision. These need to be checked in the period of three months.

Criteria: Criteria are attributes describing alternatives. It is their purpose to directly or indirectly provide information about the extent to which each alternative achieves the desired goal. As mentioned in the previous chapter, priority chains for the management of private higher education institutions are selected which need to be monitored more frequently, all for the purpose of implementing the mission and achieving the vision. The selection of criteria results from the defined missions and visions of private higher education institutions, the selection of criteria is shown in Table 2. Although the application of AHP software can lead to an increase in the number of criteria, it is suggested that the number of criteria is limited. When the number of criteria extends beyond those most important and necessary, the complexity increases and the focus of the importance of criteria shifts to the process of measuring for the purpose of measuring (Sale \& Sale, 2005). Six criteria have been defined.

Table 2: Criteria structure

\begin{tabular}{ll}
\hline Criteria & \\
\hline 1 & Employee career advancement \\
2 & Managing activities which assist in regional expansion \\
3 & Monitoring the development of cooperation with legal entities \\
4 & Monitoring the funding process \\
5 & $\begin{array}{l}\text { Simplicity to read the values of measures for the goals on the observed } \\
\text { chain (simplicity of chain computerization) } \\
6\end{array}$ \\
Damage which may result from the failure to achieve chain goals (not \\
achieving the vision or mission)
\end{tabular}

\section{Description of criteria}

- Employee career advancement - says that those chains in which the highest number of goals is aimed at developing the knowledge and skills of employees, i.e. those which help employees in advance in their careers, have the greatest weight;

- Managing activities which assist in regional expansion - this criterion assists in the selection of chains from the strategy map where the largest number of the elements supports regional expansion; 
- Monitoring the development of cooperation with legal entities - refers to the selection of those chains, i.e. greater weight is given to those chains whose elements contribute more to the development of cooperation with legal entities;

- Monitoring the funding process - greater weight is given to those cause and effect chains whose elements contribute to efficient monitoring of the funding process, i.e. which ensure funding primarily from scholarships, projects and donations;

- Simplicity to read the values of measures for the goals on the observed chain (simplicity of chain computerization)- the more independent measures of the chain can be directly "read" from the existing information system of the private higher education institution, the more preferable the chain, i.e. the greater weight it has.

- Damage which may result from the failure to achieve chain goals - this criterion assists in the selection of chains, i.e. the chain in which the failure to achieve individual goals in the chain can directly harm the achievement of vision or mission has more weight (and should therefore be monitored frequently).

\section{Model synthesis}

The three -level hierarchy was used to isolate the most important chain of the BSC to fulfil higher education institutions the vision and mission (Figure 4.). These three levels are from top to bottom:

- Goal of this AHP design;

- Criteria - described in previous chapter;

- Alternatives - BSC cause and effect chains.

Our modelling process starts with an evaluation the relative importance of each of criteria. For example, with respect to a goal, we asked how much more important is Criteria 1 relative to Criteria 2. The same question was asked to compare the relative importance of Criteria 1 and Criteria 3. This process has been continued until all possible pair wise comparisons on Criteria level have been completed.

Figure 4: The Hierarchical Structure of Problem

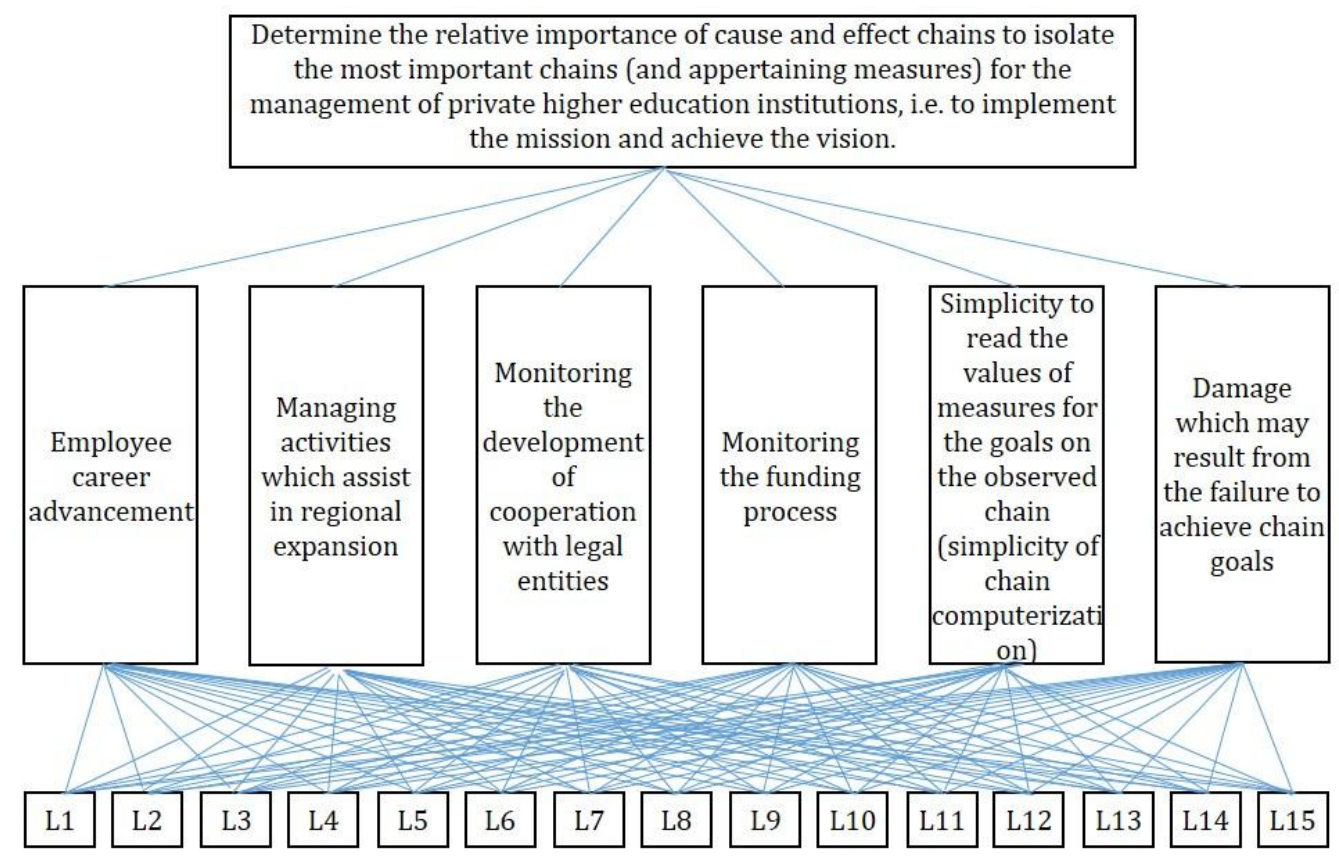

By prioritization and according to the calculation of weight for individual criteria, the greatest weight is assigned to the criterion Damage which may result from the failure to achieve chain goals, and the lowest to the criterion monitoring the development of cooperation with legal entities. The degree of consistency is 0.09 , which lies within acceptable limits (up to 0.1). By analogy, the same procedure should also be implemented to compare alternatives for individual criterion (the alternatives are pair wise compared with respect to each of the criteria.) The relative importance of each of 15 cause and effect chains (alternatives) has been addressed. For example, with respect to the each criterion, how much more 
important is L1 relative to the L2. Again comparisons has been conducted for all potential unique pairs at this third level of the hierarchy (15 comparison for each of the criteria)

For example for criterion Employee career advancement - chain $L 4$ has the greatest weight, and chain $L 9$ the lowest weight. The greatest number of goals linked into chain $L 4$ is directed at developing and improving knowledge and skills of employees. Inconsistency is 0.03 , which lies within acceptable limits. Sensitivity analysis provides a graphic overview of the effect of changed input data on the result - the change of priority of alternatives. Analysis can be carried out with respect to the goal and in relation to the selection criteria at lower hierarchy level. By application Sensitivity Analysis, one of the chains that can be isolated is the L4 chain with six goals (Raising the level of expertise of teachers, Improving the system of rewarding employees, Employee satisfaction, Student satisfaction, HS promote, Be competitive, Influx of financial resources, Increasing income) which should be monitored in shorter intervals. Taking the strategy map into account, it is evident that all four perspectives of balanced scorecards can be linked in a cause and effect framework which provides a structure for the achievement of the overall vision and mission. The observed strategy map shows that goals can be summarized into a single structured approach, where even its construction sheds light on implicit and explicit formulated strategies. Mapping strategic issues contributes to understand the nature of goals by creating a series of factors which are linked together for the purpose of achieving the mission.

\section{Conclusion}

Measurable goals are the result of a transformation of mission, vision, organization strategy, and the control of defined goals with measures for implementation is based on this relationship. One can say that the mission (and vision) is translated into clear, measurable results by which it is possible to define the success of the implementation of activities (Sale \& Sale, 2005). The paper describes how balanced scorecards, in combination with the AHP method, help form links between the mission (and vision) of private higher education institutions and measurable strategic goals. It is believed that the BSC strategy map is more than a collection of targets/critical indicators distributed within perspectives; their correlation in the cause and effect relations gives insight into organization strategies. Also the multiple criteria decision-making method (AHP) plays an important role in the described framework, demonstrating that it is possible to quantitatively link goals (causal and effect chains) with the vision and mission of the organization. It has been described in detail how this method, together with criteria selection, allows the definition of priority cause and effect chains which contain the highest number of the most important goals / strategies to achieve the vision and mission of the organization. In this way, the problem was approached structurally, with emphasis placed on objective decision-making model. The application of AHP method in this model methodology can be justified in the following manner:

- Criteria which are not easy to quantify can be used.

- The AHP help in determining a relative importance of criteria taking into account the views of different deans.

The outcome of the outlined methodology is cause and effect chains and goals which should be followed to enable better management and supervision in the private schools of higher education, with the objective of the accomplishment of mission and conveying of vision. The application of the presented model for defining generic goals and measures defines the structure for carrying out the mission and vision. One of the private schools of higher education defined its vision and mission in the following way: Vision - To operate in the Republic of Croatia with international standards and foster student development;

Mission: To equip the students with knowledge and skills for lifelong learning and make them competitive in the global market.

It is evident (from the strategy map) that the following chains should be tracked more frequently: the chain with the elements Raise the level of professional skillsC2.11 and Promote the quality of teachingC2.i2 which affect Change in the community's attitude to the private schools of higher education C1.c4, and the chain with the elements Adopt best practice in teaching C2.12 and Faster adaptation to the requirements for new skills and knowledge C2.i3. The listed elements in these two chains influence the adoption of international standards in education and the promotion of professional competence and qualification of teaching staff which directly affects the training of students and their gaining a competitive edge on the labour market, in accordance with the defined vision and mission. The results are the most important cause and effect chains, with goals which need to be monitored more frequently to allow for better management and control in private higher education institutions, for the purpose of realizing the mission and achieving the vision. 


\section{Reference}

Banchieri, L. C., Planas, F. C. \& Rebull, M. V. S. (2011). What has been said, and what remains to be said, about the balanced scorecard? Zbornikradova Ekonomskogfakulteta Rijeka, 29(1), 155-192.

Begičević, N. (2009). Odlučivanje u projektnommenadžmentu. In Divjak, B. (Ed.) Projekti u znanosti i razvoju, Europskiprogrami 180 -191, Varaždin: FOI.

Brumec, J., Tomičić, M. \& Brumec, S. (2006). Konstrukcijamjernihinstrumenata za Balanced Scorecard. Zbornikradovakonferencije Case, 18, 21-30.

Chen, S. H., Yang, C. C. \& Shiau, J. Y. (2006). The application of balanced scorecard in the performance evaluation of higher education. The TQM Magazine, 18(2), 190-205.

Chen, T. L. \& Pan, F. C. (2004). Analytic hierarchy process in an innovation integration of balanced scorecard and activity-based costing. 17th International Conference on Multiple Criteria Decision Making (MCDM 2004), Whistler, B. C. Canada

Dobrović, Ž. (2000). Strategic planning under uncertainty: building the meta model. Zbornikradova, 25(1), 11-26.

Doolan, K. (2001). Reconfiguring higher education: discourses and practices, Contemporary Croatia: Development Challenges in a Socio-Cultural Perspective, Lisbon:Edicoes Universitarias Lusofonas, pp. 75-100 (ISBN: 978-972-8881-97-9)

Erbasu, B. \& Parlakkaya, R. (2012). The use of Analytic Hierarchy Process in the Balanced Scorecard: An Approach in a Hotel Firm. Business and Management Review, 2(2), 23 - 37.

Farrokhi, M. M., Alireza-Aftabi, A. \& Hemati, M. (2012). Evaluation and Weighting Balanced Scorecard Critical Factors by Means of Fuzzy Analytic Hierarchy Process (A Case Study). World Applied Sciences Journal, 16 (2).

Harmon, P. (2003). Business process changes - a manager's guide to improving, redesigning, and automating processes. San Francisko: Morgan Kaufmann Publishers, 462.

Hunjak, T. \& Jakovčević, D. (2003). Višekriterijskimodeli za rangiranje i uspoređivanjebanaka. ZbornikEkonomskogfakulteta u Zagrebu, 1(1), 43-60.

Jandrić, Z. \& Srđević, B. (2000). Analitičkihijerarhijskiproceskaopodrškadonošenjuodluka u vodoprivredi. Jugoslavenskičasopis Vodoprivreda, 32, 327-337.

Kaplan, R. \& Norton, D. (1996). Translating strategy into action The Balanced Scorecard, Boston, Massachusetts: Harvard Business School Press.

Koo, L. C. \& Koo, H. (2007). Holistic approach for diagnosing, prioritizing, implementing and monitoring effective strategies through synergetic fusion of SWOT, Balanced Scorecard and QFD. World Review of Entrepreneurship, Management and Sust. Development, 3(1), 62-78.

Penić, S. \& Dobrović, Ž. (2008). Managing Private Higher Learning Institutions with the support of Information Technology: Strategic Framework, CEIIS 19th International Conference, 325 332., Varaždin

Penić, S. (2008). Sefiniranjegeneričkihciljeva i mjera upravljanjeprivatnimvisokimškolamametodomuravnoteženihbodovnihtablica. Published master thesis, FOI, Varaždin

Rigby, D. \& Bilodeau, B. (2010). Management Tools and Trends 2009, presentation, Retrieved from http://www.bain.com/management_tools/Management_Tools_and_Trends_2009_Global_Resul ts.pdf on 25.05.2012.

Saaty, L. T. \& Begicevic, N. (2010). The scope of human values and human activities in decision making. Applied Soft Computing, 10, 963-974.

Sale, R. S. \& Sale M. L. (2005). Lending validity and consistency to performance measurement. Managerial Auditing Journal, 20(9), 915-927.

Shojaie, A. A., Torabi, G. \& Sedighi, M. M. (2012). Proposing a novel method for assessment of Knowledge Management performance using Balanced Scorecard. Wulfenia Journal, 19(8), 355365.

Theriou, N. G., Demitriades, E. \& Chatzoglou, P. (2004). A Proposed Framework For Integrating The Balanced Scorecard Into The Strategic Management Process. Operational Research, 4(2), 147 165.

Tomčić, M. \& Dobrović, Ž. (2006). Metodeoblikovanjastrateškemapeciljevakodizgradnje BSC. Zbornikradovakonferencije Case, 18, 13-19, Opatija.

Varma, S., Wadhwa, S. \& Deshmukh, S. G. (2008). Evaluating petroleum supply chain performance Application of analytical hierarchy process to balanced scorecard. Asia Pacific Journal of Marketing and Logistics, 20(3), 343-356. 